Original Article

\title{
The predatory mite Neoseiulus californicus (Acari: Phytoseiidae) does not respond for volatiles of maize infested by Tetranychus urticae (Acari: Tetranychidae)
}

\author{
O ácaro predador Neoseiulus californicus (Acari: Phytoseiidae) não responde aos \\ voláteis de milho infestado por Tetranychus urticae (Acari: Tetranychidae)
}

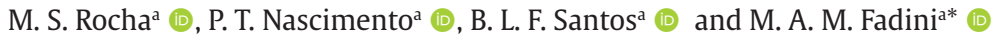 \\ ${ }^{a}$ Universidade Federal de São João Del Rei - UFSJ, Departamento de Ciências Agrárias, Sete Lagoas, MG, Brasil
}

\begin{abstract}
Among the plants defense mechanisms, the induction and emission of volatile organic compounds, which can be used to attract natural enemies, such predators insects. Although well studied, the induction of plant volatiles that attract natural enemies can vary according to intensity of infestation of herbivores and the species of host plant. We investigated the olfactory behavioral responses of the predatory mite Neoseiulus californicus (McGregor) (Acari: Phytoseiidae) to the volatiles of infested maize (Zea mays) plants by the two-spotted spider mite Tetranychus urticae (Koch, 1836) (Acari: Tetranychidae) in early and advanced infestations. The Bt (Viptera) maize cultivar Impact ${ }^{\circledR}$ was used for tests the behavior of $N$. californicus. After initial and advanced infestations, the phytophagous mites T. urticae were removed, and the plants were tested using a "Y" olfactometer. The following treatments were evaluated: air vs. air, uninfested plants vs. air, uninfested plants vs. plants infested with 10 females of T. urticae, uninfested plants vs. plants infested with 100 females of $T$. urticae, uninfested plants vs. plants infested with 200 females of T. urticae and plants infested with $10 \mathrm{vs}$. plants infested with 200 females of $T$. urticae. The predatory mite $N$. californicus did not show preference to the treatments tested, suggesting that maize plants infested by T. urticae do not induce volatiles capable of attracting the predatory mite $N$. californicus. We concluded that $N$. californicus is not attracted by maize plants infested by T. urticae.
\end{abstract}

Keywords: biological control, induced plant resistance, chemical ecology, two-spotted spider mite.

\begin{abstract}
Resumo
Dentre os mecanismos de defesa de plantas, a indução e emissão de compostos orgânicos voláteis, podem ser utilizados para atrair inimigos naturais, como insetos predadores. Embora bem estudada, a indução dos voláteis de plantas que atraem inimigos naturais pode variar de acordo com a intensidade de infestação de herbívoros e a espécie de planta hospedeira. Investigamos as respostas comportamentais olfativas do ácaro predador Neoseiulus californicus (McGregor) (Acari: Phytoseiidae) aos voláteis de plantas infestadas pelo ácaro-rajado Tetranychus urticae (Koch, 1836) (Acari: Tetranychidae). A cultivar de milho Bt (Viptera) Impact ${ }^{\circledR}$ foi utilizada para testar o comportamento de $N$. californicus. Após infestações iniciais e avançadas, os ácaros fitófagos T. urticae foram removidos e as plantas testadas em olfatômetro "Y". Os seguintes tratamentos foram avaliados: ar vs. ar, plantas não infestadas vs. ar, plantas não infestadas vs. plantas infestadas com 10 fêmeas de T. urticae, plantas não infestadas vs. plantas infestadas com 100 fêmeas de T. urticae, plantas não infestadas vs. plantas infestadas com 200 fêmeas de T. urticae e plantas infestadas com 10 vs. plantas infestadas com 200 fêmeas de T. urticae. 0 ácaro predador $N$. californicus não mostrou preferência aos tratamentos testados, sugerindo que plantas de milho infestadas por T. urticae não induzem voláteis capazes de atrair o ácaro predador $N$. californicus. Concluímos que N. californicus não é atraído por plantas de milho infestadas por T. urticae.
\end{abstract}

Palavras-chave: controle biológico, resistência induzida de plantas, ecologia química, ácaro-rajado.

\section{Introduction}

Plants emit constitutively volatile organic compounds (VOCs) that are exploited by herbivorous insects to locate their host plant (Dicke, 1998; Dicke and Van Loon, 2000). However, when attacked, plants respond to injury caused by herbivores, producing chemical signals known as herbivory-induced plant volatiles (HIPV's) (Pare and Tumlinson, 1997; Turlings and Erb, 2018). HIPV's are used by predators and parasitoids as chemical cues, to direct

*e-mail: fadini@ufsj.edu.br

Received: June 16, 2020 - Accepted: October 22, 2020 
foraging and increase the rate of encounter with their prey or hosts (Kessler and Baldwin, 2001).

Different species of herbivores can induce different volatile organic compounds (Naranjo-Guevara et al., 2017). This emission varies in a complex way, and may be related to the light-dark cycle and the feeding method of the herbivorous insect (Vercammen et al., 2001). Predatory mite foraging by plant-induced volatiles may reduce populations of phytopathous mites by biological control (Dicke et al., 1990).

The study of plant defense mechanisms, as well as their interaction with arthropods, can assist in understanding biochemical and evolutionary relationships between plants and natural enemies (Chen, 2008). Thus, this information can be used as a tool to reduce the attack of herbivores and support biological control programs (Turlings et al., 1998). Therefore, the investigation of the tritrophic relationships, as well as the study of the induction of volatiles production by plants and the attractive activity of these compounds are fundamental components to apply an effective biological control of mites.

The two-spotted spider mite Tetranychus urticae Koch (Acari: Tetranychidae) is one of the main species of polyphagous pests of vegetables and other crops (Liburd et al., 2007; Grbić et al., 2011; Reichert et al., 2017). In North America T. urticae is considered a pest on maize, resulting in significant production losses (Barron and Margolies, 1991). However, recent research indicates that the two-spotted spider mite may turn out to be a possible pest in maize crop in Brazil (Botti et al., 2019). The injuries and damages caused by this mite species can be drastic when in favorable conditions (Marafeli et al., 2014; Castro et al., 2019). So, it is indispensable researches that study the behavior of this organism in maize, aiming to control of this mite population and, consequently, avoiding yield losses.

Although many behavioral and chemical aspects of plant volatiles are well studied, the results reported on maize are not clear (Shimoda et al., 2005; Botti et al., 2019). In some cases, plant volatiles induced by herbivory do not attract natural enemies. However, the same phytophagous can trigger or not defenses in different plants (Botti et al., 2019). Li et al. (2002) showed that T. urticae induces a rapid defense response regulated by jasmonate in tomatoes. On the other hand, Botti et al. (2019) showed that the predatory mite Neoseiulus californicus (McGregor) (Acari: Phytoseiidae) does not present an olfactory response to the volatiles of maize plants under initial infestation. Those authors suggest that the predator's preference could be influenced by the level of infestation of herbivores. Thus, it is relevant to evaluate the levels of $T$. urticae infestations in maize and the olfactory response of the predatory mite $N$. californicus. Thus, the hypothesis tested in this work is: the infestation density of T. urticae would interfere in the olfactory response of $N$. californicus by indirect defenses induced by maize plants. So, the objective of this work was to evaluate the olfactory response of the predator $N$. californicus to maize plants infested by the two-spotted spider mite T. urticae in recent and advanced infestations.

\section{Materials and Methods}

\subsection{Greenhouse plant cultivation}

Seeds of commercial Bt (VIP3Aa20) maize hybrid, Impacto $^{\circledR}$ (Viptera, insect resistant), from Syngenta ${ }^{\circledR}$ was sown in 1-L polyethylene pots filled with Terral Solo ${ }^{\circledR}$ substrate. Maize plants were growing in greenhouse maintained at temperature between $25 \pm 5{ }^{\circ} \mathrm{C}$ and irrigated every other day. Plants were used in the bioassays 10-12 days after emergence when they had three fully expanded leaves (V3).

\subsection{Rearing of two-spotted spider mite, and predatory mite}

Infested leaves of sorghum plants (Sorghum bicolor, L. Moench) with T. urticae were collected in the greenhouse. To establish colonies, adult mites were collected, individually using a stereomicroscope and a hair brush to transfer the mites to jack bean plants (Canavalia ensiformis) with two completely expanded cotyledon leaves and without phytosanitary treatment. The bean plants were cultivated in 1.0 L plastic pots using Terral Solo ${ }^{\circledR}$ substrate. Infested plants were kept isolated in screened cages to prevent external infestation with other herbivores. The predatory mite $N$. californicus was obtained from the Koppert Biological Systems Company.

\subsection{Olfactory response}

Each maize plant was infested with 10, 100 and 200 adult females of $T$. urticae. After $24 \mathrm{~h}$ of infestation, plants were used in Y-tube olfactometer to test the following treatments: (i) clean plants vs. infested plants with a density of $10 \mathrm{~T}$. urticae females; (ii) clean plants vs. plants infested with 100 females of $T$. urticae; (iii) clean plants vs. plants infested with 200 females of T. urticae and (iv) plants infested with 10 vs. plants infested with 200 females of $T$. urticae.

A Y-tube olfactometer was used to study the response of $N$. californicus. The glass Y-Tube (with dimensions of $21.0 \mathrm{~cm}$ of length of each arm and $3.5 \mathrm{~cm}$ of diameter) had a Y-shaped metal wire inside to facilitate the movement of mites. A container, consisting of a plastic box, was attached to each arm of the Y-tube. The Y-tube base was connected to a vacuum pump that directed the flow from the containers to the Y-tube arms. The predators were individually introduced at the starting point on the steel wire and then observed until a predator reached $1 / 3$ of an arm, where the mite response was considered. Predatory mites that did not pass $1 / 3$ of either arm within 300 seconds were accounted unresponsive. After every five responses, the odor sources positions were reversed.

The plants used as odor sources were placed inside glass containers (height, $70.0 \mathrm{~cm}$, width, $25.0 \mathrm{~cm}$, length, $35.0 \mathrm{~cm}$ ), where the ends of the olfactometer were connected. Infestations of 10 females were considered low and those with 100 and 200 females as high. For each treatment there were used three true replicates (i.e. odor sources), and, for each repetition, 20 predatory mites were individual evaluated. 


\subsection{Statistical analyzes}

The data of predatory mite behavior in the olfactometer were submitted to chi-square tests for categorical data (Crawley, 2013). Predatory mites that did not choose one of the olfactometer arms after five minutes were not considered for analysis. The analyses were performed using $R$ software version 3.0.2 ( $R$ Development Core Team 2014). It was used crude and sum of predatory olfactory response data to perform the chi-square test. This way, it produced a more robust results from data.

\section{Results}

The predatory mite $N$. californicus did not show preference to air vs. air, demonstrating that the olfactometer used was calibrated and did not present trends for the behavior of the evaluated predatory mite $\left(\chi^{2}=0.00, p=1.000\right.$, from sum of data) (Figure 1A). As expected, $N$. californicus also did not show preference in the treatment between air vs. clean plant $\left(\chi^{2}=0.60\right.$, $\mathrm{p}=0.439$, from sum of data) (Figure $1 \mathrm{~B}$ ). The same was observed among corn plant without infestation vs. maize plant infested by 10 females of $T$. urticae ( $\chi^{2}=0.72, p=$ 0.396 , from sum of data) (Figure 1C).

The predatory mite N. californicus did not show preference in the treatment between maize plants without infestation vs. maize plants infested by 100 adult females of T. urticae $\left(\chi^{2}=8.06, p=0.050\right.$, from sum of data) (Figure $2 A$ ), the same occurred with the treatments between maize plants without infestation vs. plants of maize infested by 200 adult females of $T$. urticae $\left(\chi^{2}=0.00, p=1.000\right.$, from sum of data) (Fig 2B) and maize plants infested by $10 \mathrm{vs.}$ 200 adult females of $T$. urticae $\left(\chi^{2}=0.00, p=1.000\right.$, from sum of data) (Figure 2C).

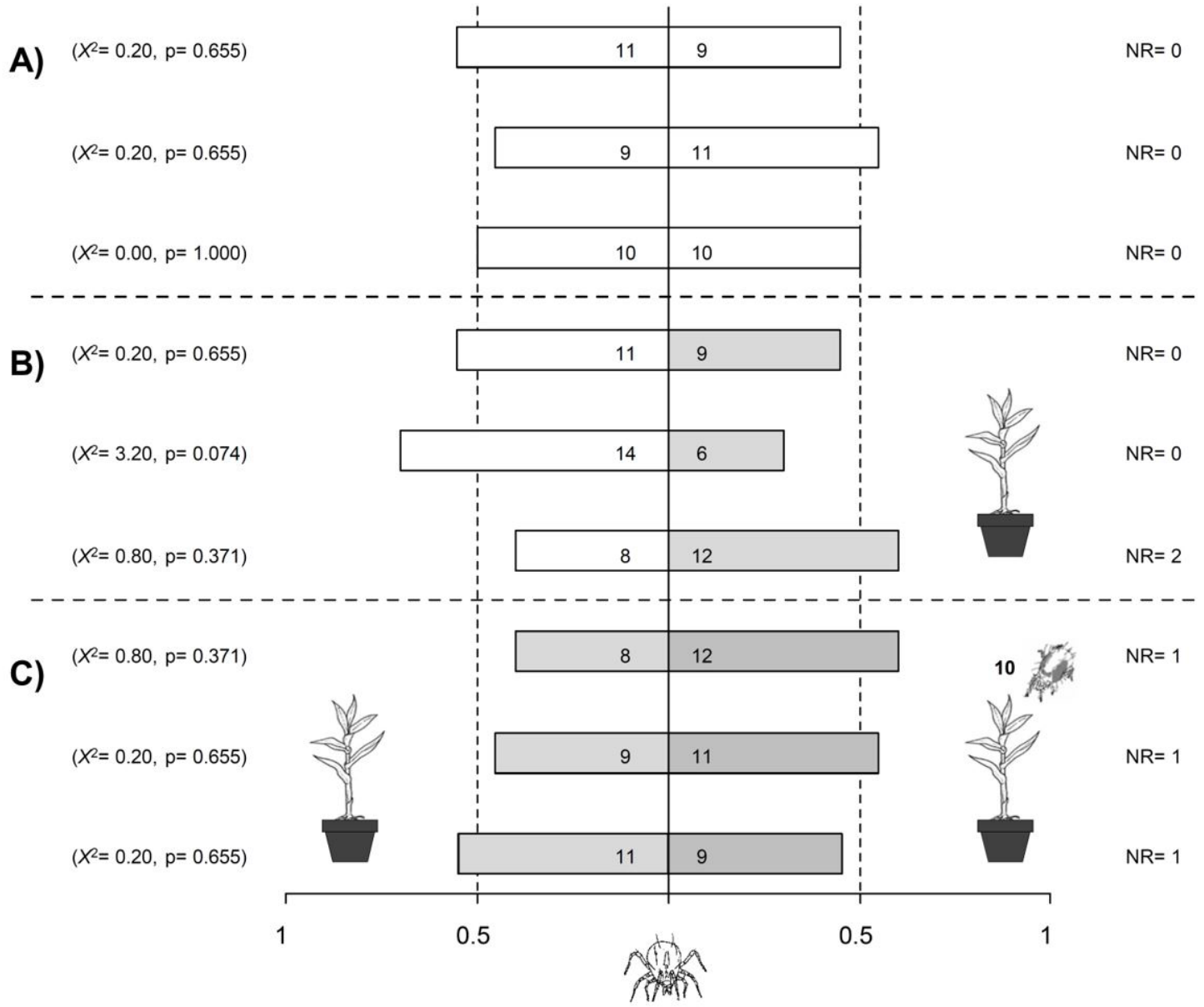

Figure 1. Olfactory response of Neoseiulus californicus in Y-olfactometer. (A) air vs. air (white bars), (B) air vs. maize plants without infestation and (C) maize plants without infestation vs. maize plants infested by ten adult females of T. urticae. NR represents nonresponsive insects (no choice). Chi-square test with $5 \%$ significance. Numbers in bars represent individual predator that choose the indicated odor. The number of predatory mite without response to the treatments (NR), after 5 minutes, was eliminated from the statistical analysis. 


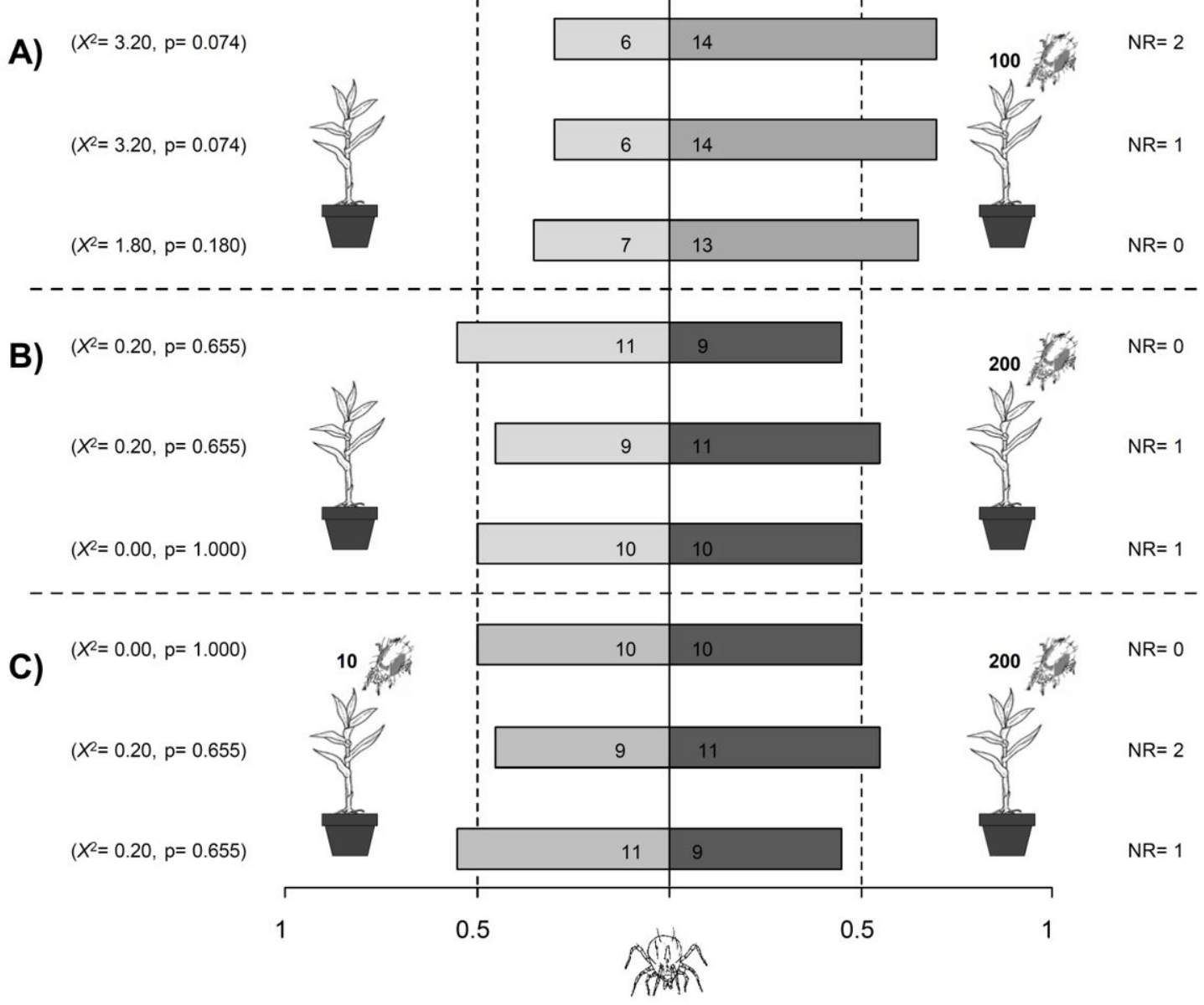

Figure 2. Olfactory response of Neoseiulus californicus in Y-olfactometer. (A) maize plants without infestation vs. maize plants infested by 100 adult females of $T$. urticae, (B) maize plants without infestation vs. maize plants infested by 200 adult females of $T$. urticae and (C) maize plants infested by ten vs. 200 adult females of $T$. urticae. NR represents non-responsive insects (no choice). Chi-square test with $5 \%$ significance. Numbers in bars represent individual predator that choose the indicated odor. The number of predatory mite without response to the treatments (NR), after 5 minutes, was eliminated from the statistical analysis.

\section{Discussion}

The predatory mite was not attracted to maize plants previously infested with $T$. urticae compared to the uninfested ones. Several studies have already shown that volatiles compounds produced in response to $T$. urticae attack are attractive to natural enemies. Shimoda et al. (2005) demonstrated that bean plants infested with $T$. urticae are attractive to the predatory mite $N$. californicus compared to the ones uninfested. However, in the present study, tests involving clean maize plants vs. infested plants did not attrack the predatory mite $N$. californicus, in any level of T. urticae previous infestation, 10,100 or 200 mites per plant. A similar result was observed by Botti et al. (2019), testing the preference of $N$. californicus in initial infestations with T. urticae in maize plants. Therefore, it is assumed that the same phytophagous organism may or may not cause defenses induced in different plants, since the release of volatiles can be quite different among plant species (Turlings et al., 1998).

A possible hypothesis to explain the results obtained in this work would be that of the reduced period of coevolution between maize plants and phytophagous mites of the species T. urticae. Considering the evolutionary time, the recent interaction between the mite species and maize plants was not enough to make selection pressure to develop an induced defense mechanism. Also, the low level of damage caused by the two-spotted spider mites prevented the plants of the studied cultivar from developing structures of induced defenses capable of attracting the predatory mite $N$. californicus. Dicke et al. (2009) explain that the induced defenses can respond to biotic stress through chemical phenotypic changes, which can affect on an evolutionary and ecological time scale, generating consequences on interactions between species, thus reflecting the contact between members of the community. Thus, it is assumed that maize plants still need to have 
a more intense interaction with the two-spotted spider mite, allowing selection pressure and, consequently, the development of defense structures in response to the attack of $T$. urticae populations. Such conjectures are amenable and should be tested as hypotheses in future work.

\section{Conclusions}

The related study shows that the predator $N$. californicus is not attracted to maize plants infested with T. urticae. The inability of the predatory mite to identify volatiles compounds reduce the chances of T. urticae be controlled by $N$. californicus in the maize crop, due to this difficulty in meeting prey and natural enemy and consequently reducing the biological control rate in the field. Therefore, maize plants when infested with $T$. urticae do not induce volatiles capable of attracting the predatory mite $N$. californicus.

\section{Acknowledgements}

The authors thank the Federal University of São João del-Rei, for scientific support and the Fundação de Amparo à Pesquisa do Estado de Minas Gerais (FAPEMIG), for the financial support. Also, the authors thank Dr. J.M. Waquil, for the English review and suggestions in original manuscript.

\section{References}

BARRON, J.A. and MARGOLIES, D.C., 1991 [viewed 16 June 2020 ]. Within-plant dispersal of banks grass mite (Acari: Tetranychidae) on corn. Journal of the Kansas Entomological Society [online], vol. 64, no. 2, pp. 209-215. Available from: https://www.jstor. org/stable/25085272

BOTTI, J.M.C., FRANZIN, M.P., FADINI, M.A.M. and MELO, J.O.L., 2019. Preference of Neoseiulus californicus (Acari: Phytoseiidae) for volatiles of $B t$ maize induced by multiple herbivory. Revista Brasileira de Entomologia, vol. 63, no. 4, pp. 283-289. http:// dx.doi.org/10.1016/j.rbe.2019.09.003.

CASTRO, B.M.C., SOARES, M.A., ANDRADE JÚNIOR, V.C., SANTOS JÚNIOR, V.C., FONTES, P.C.R., WILCKEN, C.F., SERRÃO, J.E. and ZANUNCIO, J.C., 2019. Preference of red mite Tetranychus ludeni Zacher (Acari: Tetranychidae) to sweet potato genotypes. Brazilian Journal of Biology = Revista Brasileira de Biologia, vol. 79, no. 2, pp. 208-212. http://dx.doi.org/10.1590/1519-6984.176665. PMid:29947646.

CHEN, M.S., 2008. Inducible direct plant defense against insect herbivores: a review. Insect Science, vol. 15, no. 2, pp. 101-114. http://dx.doi.org/10.1111/j.1744-7917.2008.00190.x.

CRAWLEY, M.J., 2013. The R book. 2nd ed. Chichester: JohnWiley \& Sons. no. 2.

DICKE, M., 1998. Induced responses to herbivory by R. Karban and I.T. Baldwin. Trends in Ecology \& Evolution, vol. 13, no. 2, pp. 83. http://dx.doi.org/10.1016/S0169-5347(97)01267-6. PMid:21238211.

DICKE, M. and VAN LOON, J.J.A., 2000. Multitrophic effects of herbivore-induced plant volatiles in an evolutionary context. Entomologia Experimentalis et Applicata, vol. 97, no. 3, pp. 237-249. http://dx.doi.org/10.1046/j.15707458.2000.00736.x.
DICKE, M., VAN LOON, J.J.A. and SOLER, R., 2009. Chemical complexity of volatiles from plants induced by multiple attack. Nature Chemical Biology, vol. 5, no. 5, pp.317-324. http://dx.doi. org/10.1038/nchembio.169. PMid:19377458.

DICKE, M., VANBEEK, T.A., POSTHUMUS, M.A., BEN DOM, N., VAN BOKHOVEN, H. and DE GROOT, A., 1990. Isolation and identification of volatile kairomone that affects Acarine predatorprey interactions: involvement of host plant in its production. Journal of Chemical Ecology, vol. 16, no. 2, pp. 381-396. http:// dx.doi.org/10.1007/BF01021772. PMid:24263497.

GRBIĆ, M., VAN LEEUWEN, T., CLARK, R.M., ROMBAUTS, S., ROUZÉ, P., GRBIĆ, V., OSBORNE, E.J., DERMAUW, W., THI NGOC, P.C., ORTEGO, F., HERNÁNDEZ-CRESPO, P., DIAZ, I., MARTINEZ, M., NAVAJAS, M., SUCENA, É., MAGALHÃES, S., NAGY, L., PACE, R.M., DJURANOVIĆ, S., SMAGGHE, G., IGA, M., CHRISTIAENS, O., VEENSTRA, J.A., EWER, J., VILLALOBOS, R.M., HUTTER, J.L., HUDSON, S.D., VELEZ, M., YI, S.V., ZENG, J., PIRES-DASILVA, A., ROCH, F., CAZAUX, M., NAVARRO, M., ZHUROV, V., ACEVEDO, G., BJELICA, A., FAWCETT, J.A., BONNET, E., MARTENS, C., BAELE, G., WISSLER, L., SANCHEZRODRIGUEZ, A., TIRRY, L., BLAIS, C., DEMEESTERE, K., HENZ, S.R., GREGORY, T.R., MATHIEU, J., VERDON, L., FARINELLI, L., SCHMUTZ, J., LINDQUIST, E., FEYEREISEN, R. and VAN DE PEER, Y., 2011. The genome of Tetranychus urticae reveals herbivorous pest adaptations. Nature, vol. 479, no. 7374, pp. 92-487. http:// dx.doi.org/10.1038/nature10640. PMid:22113690.

KESSLER, A. and BALDWIN, I.T., 2001. Defensive function of herbivore-induced plant volatile emissions in nature. Science, vol. 291, no. 5511, pp. 2141-2144. http://dx.doi.org/10.1126/ science.291.5511.2141. PMid:11251117.

LI, C.Y., WILLIAMS, M.M., LOH, Y.T., LEE, G.I. and HOWE, G.A., 2002. Resistance of cultivated tomato to cell content-feeding herbivores is regulated by the octadecanoid-signaling pathway. Plant Physiology, vol. 130, no. 1, pp. 494-503. http://dx.doi. org/10.1104/pp.005314. PMid:12226528.

LIBURD, O.E., WHITE, J.C., RHODES, E.M. and BROWDY, A.A., 2007. The residual and direct effects of reduced risk and conventional miticides on two-spotted spider mites, Tetranychus urticae (Acari: Tetranychidae), and predatory mites (Acari: Phytoseiidae). The Florida Entomologist, vol. 90, no. 1, pp. 249-257. http://dx.doi. org/10.1653/0015-4040(2007)90[249:TRADEO]2.0.CO;2.

MARAFELI, P.P., REIS, P.R., SILVEIRA, E.C., SOUZA-PIMENTEL, G.C. and TOLEDO, M.A., 2014. Life history of Neoseiulus californicus (McGregor, 1954) (Acari: Phytoseiidae) fed with castor bean (Ricinus communis L.) pollen in laboratory conditions. Brazilian Journal of Biology = Revista Brasileira de Biologia, vol. 74, no. 3, pp. 691-697. http://dx.doi.org/10.1590/bjb.2014.0079. PMid:25296220.

NARANJO-GUEVARA, N., PEÑAFLOR, M.F.G.V., CABEZAS-GUERRERO, M.F. and BENTO, J.M.S., 2017. Nocturnal herbivore-induced plant volatiles attract the generalist predatory earwig Doru luteipes Scudder. Naturwissenschaften, vol. 104, no. 77, pp. 9-10. http:// dx.doi.org/10.1007/s00114-017-1498-9.

PARE, P.W. and TUMLINSON, J.H., 1997. De novo biosynthesis of volatiles induced by insect herbivory in cotton plants. Plant Physiology, vol. 114, no. 4, pp. 1161-1167. http://dx.doi. org/10.1104/pp.114.4.1161. PMid:12223763.

RDEVELOPMENT CORE TEAM, 2014. R: a language and environment for statistical computing. Vienna: R Foundation for Statistical Computing.

REICHERT, M.B., TOLDI, M., RODE, P.A., FERLA, J.J. and FERLA, N.J., 2017. Biological performance of the predatory mite Neoseiulus idaeus (Phytoseiidae): a candidate for the control of tetranychid mites in Brazilian soybean crops. Brazilian Journal of Biology = Revista Brasileira de Biologia, vol. 77, no. 2, pp. 361-366. http:// dx.doi.org/10.1590/1519-6984.14915. PMid:27533728. 
SHIMODA, T., OZAWA, R., SANO, K., YANO, E. and TAKABAYASHI, J., 2005. The involvementof volatile infochemicals from spider mites and from food-plants in prey loca-tion of the generalist predatory mite Neoseiulus californicus. Journal of Chemical Ecology, vol. 31, no. 9, pp. 2019-2032. http://dx.doi.org/10.1007/ s10886-005-6075-6. PMid:16132210.

TURLINGS, T.C.J. and ERB, M., 2018. Tritrophic interactions mediated by herbivore-induced plant volatiles: mechanisms, ecological relevance, and application potential. Annual Review of Entomology, vol. 63, no. 1, pp. 433-452. http://dx.doi.org/10.1146/ annurev-ento-020117-043507. PMid:29324043.
TURLINGS, T.C.J., LENGWILER, U.B., BERNASCONI, M.L. and WECHSLER, D., 1998. Timing of induced volatile emissions in maize seedlings. Planta, vol. 207, no. 1, pp. 46-152. http:// dx.doi.org/10.1007/s004250050466.

VERCAMMEN, J., PHAM-TUAN, H. and SANDRA, P., 2001. Automated dynamic sampling system for the on-line monitoring of biogenic emissions from living organisms. Journal of Chromatography. A, vol. 930, no. 1-2, pp. 3951. http://dx.doi.org/10.1016/S0021-9673(01)01172-4. PMid:11681578. 